\title{
Stabilometric assessment of static balance and postural stability in multicanal vertigo post vestibular rehabilitation: a clinical case report
}

\author{
Análise estabilométrica do equilíbrio estático e estabilidade postural na vertigem multicanal pós \\ reabilitação vestibular: relato de caso clínico \\ Análisis estabilométrico del equilíbrio estático y estabilidad postural en vértigo multicanal tras \\ rehabilitación vestibular: reporte de un caso clínico
}

Received: 12/11/2020 | Reviewed: 20/11/2020 | Accept: 23/08/2021 | Published: 24/08/2021

\author{
Lucas Marques Fortunato \\ ORCID: https://orcid.org/0000-0001-6704-3126 \\ Universidade Federal do Paraná, Brazil \\ E-mail: lucasmarquesfortunato@gmail.com \\ Lucélia Luna Melo-Diaz \\ ORCID: https://orcid.org/0000-0002-2347-1257 \\ Universidade Federal do Paraná, Brazil \\ E-mail: mluluna@gmail.com
}

\begin{abstract}
Introduction: Multicanal vertigo is a rare disorder and vestibular rehabilitation is one of the treatment methods, aiming to stimulate the neuroplasticity of the central nervous system. Objective: To examine the effect of a vestibular rehabilitation program on static balance and postural stability in an individual with vertigo. Case report: Male patient, 58 years old, with clinical diagnosis of benign paroxysmal positional vertigo for 12 years, with frequent episodes of vertigo, loss of balance and falls. The assessment of balance and postural stability were performed using the Romberg test with eyes open and closed, on a S-Plate v.14 - Medicapteurs - France, force platform, analysing data at a risk of $\mathrm{p}<0.05$ level. After the Epley's Maneuver, the vestibular rehabilitation program was started. It consisted of CawthorneCooksey vestibular exercises, the Brandt-Daroff modified maneuver, and the Norre's vestibular habituation training, twice a week, for a total of 10 sessions. Results: The tests performed with eyes open, did not show a statistically significant difference between pre and post treatment. However, in the stabilometric analysis, the wave width, the mean deviation, and the mean speed in the anteroposterior $(\mathrm{A} / \mathrm{P})$ and latero-lateral $(\mathrm{L} / \mathrm{L})$ displacements in $\mathrm{mm} / \mathrm{s}$, as well as the postural stability for the eyes closed tests had a statistically significant improvement. Conclusion: Vestibular rehabilitation was effective in improving static balance and postural stability in this case report, scientifically corroborating the importance of the chosen rehabilitation method as a viable option for the treatment of peripheral vestibulopathy.
\end{abstract}

Keywords: Vertigo; Balance; Postural stability; Vestibular rehabilitation.

\begin{abstract}
Resumo
Introdução: A vertigem multicanal é uma desordem rara e uma das formas de tratamento é a reabilitação vestibular que objetiva a estimulação da neuroplasticidade do sistema nervosos central. Objetivo: Verificar o efeito de um programa de reabilitação vestibular na melhora do equilíbrio estático e estabilidade postural de um indivíduo com vertigem. Relato de caso: Paciente do sexo masculino, 58 anos, com diagnóstico clínico há 12 anos de vertigem de posicionamento paroxística benigna, com crises vertiginosas frequentes e histórico de desequilíbrio e quedas. A avaliação do equilíbrio e estabilidade postural foi realizada com o teste de Romberg com olhos abertos e fechados, em cima de uma plataforma de força da marca S-Plate v.14 - Medicapteurs - France, analisando os dados com risco de p<0,05. Após a manobra de Epley, iniciou-se o programa de reabilitação vestibular composto de exercícios vestibulares de Cawthorne e Cooksey, Brandt-Daroff modificado e treinamento de habituação vestibular de Norré, duas vezes por semana, totalizando 10 sessões. Resultados: Os testes realizados com os olhos abertos não apresentaram diferenças significativas pré e pós tratamento. Contudo na análise estabilométrica da largura da onda, média de desvio e média de velocidade nos deslocamento ântero-posterior (A/P) e látero-lateral (L/L) em mm/s, bem como a estabilidade postural nos testes com os olhos fechados apresentam melhora significativa. Conclusão: A reabilitação vestibular mostrou-se eficiente na melhora do equilíbrio estático e estabilidade postural no caso estudado, corroborando cientificamente com a importância do método de reabilitação escolhido como uma opção viável para o tratamento da vestibulopatia periférica.
\end{abstract}

Palavras-chave: Vertigem; Equilíbrio; Estabilidade postural; Reabilitação vestibular. 


\begin{abstract}
Resumen
Introducción: El vértigo multicanal es raro y una de las formas de tratamiento es la rehabilitación vestibular que tiene como objetivo estimular la neuroplasticidad del sistema nervioso central. Objetivo: Verificar el efecto de un programa rehabilitación vestibular sobre el equilibrio estático y la estabilidad postural en un individiuo con vértigo. Caso clínico: Paciente masculino de 58 años, con diagnóstico clínico de vértigo posicional paroxístico benigno desde hace 12 años, con frecuentes crisis de vértigo y antecedente de desequilibrio y caídas. La evaluación del equilibrio y la estabilidad postural se realizó mediante la prueba de Romberg con ojos abiertos y cerrados sobre una plataforma de fuerza de la marca S-Plate v.14-Medicapteurs-Francia, analizando datos con riesgo de p $<0,05$. Después de la maniobra de Epley, se inició el programa de rehabilitación vestibular que consiste en ejercicios vestibulares de Cawthorne y Cooksey, la maniobra modificada de Brandt-Daroff y el entrenamiento de habituación vestibular de Norré, dos veces por semana, para un total de 10 sesiones. Resultados: Las pruebas realizadas con los ojos abiertos, no mostraron diferencias estadísticamente significativas antes y después del tratamiento. Sin embargo, en el análisis estabilométrico, el ancho de onda, la desviación media y la velocidad media posición postural en los desplazamientos anteroposterior (A/P) y laterolateral (L/L) en mm/s, así como la estabilidad postural en las pruebas con los ojos cerrados muestran una mejora estadísticamente significativa. Conclusión: La rehabilitación vestibular demostró ser eficaz para mejorar el equilíbrio estático y la estabilidad postural en el caso estudiado, corroborando científicamente la importancia del método de rehabilitación elegido como una opción viable para el tratamiento de la vestibulopatía periférica.
\end{abstract}

Palabras clave: Vértigo; Equilibrio; Estabilidad postural; Rehabilitación vestibular.

\title{
1. Introduction
}

Postural instability has been one of the greatest public health concerns, and it is directly related to risk of falls. Stabilometry is a technique that assesses postural instability. It consists of assessing body balance in orthostatic posture and quantifying the oscillations coming from the individual's body while standing on a force platform (Menezes, et al., 2020; Pimentel, et al., 2020).

Benign paroxysmal positional vertigo (BPPV) is one of the disorders of the peripheral vestibular system. It is a type of peripheral vestibular disease that causes vertigo, characterized by the appearance of rotational dizziness that arises in certain positions of the head (Oliveira, et al., 2020).

Vestibular rehabilitation is one of the treatment options for BPPV. It is a therapy with no side effects, based on habitual exercises with the objective of stimulating the central nervous system in order to reduce symptoms. It is a therapeutic resource used as a treatment in patients with a body balance disorder, based on plasticity mechanisms of the central nervous system (Pires, et al., 2019).

There is limited research on this topic, as well as on its different designs. Therefore, the purpose of this study was to verify the effect of a vestibular rehabilitation program on static balance and postural stability in an individual with a clinical diagnosis of benign paroxysmal positional vertigo.

\section{Methodology}

This is a descriptive, clinical case report study of an individual with multicanal benign paroxysmal positional vertigo (Pereira, et al., 2018). After providing a written free and informed consent, the participant underwent a vestibular rehabilitation program in order to assess balance and postural stability using static baropodometry.

Data from the pre- and post-treatment were analyzed using the S-Plate v 1.4 - Medicapteurs - France, a software program from the platform, calculated at the $\mathrm{p}<0.05$ risk level.

\section{Clinical Case Report}

This clinical case report assessed a male patient, 58 years old, with a clinical diagnosis of unilateral BPPV due to anterior and posterior ductolithiasis of the semicircular canal. 
An initial assessment, consisting of anamnesis, physical examination, and physical therapy assessment was conducted. The anamnesis indicated that the clinical diagnosis was made 12 years ago, and the patient has had frequent episodes of vertigo, loss of balance, and history of falls.

Static balance was assessed using the Romberg test with eyes open and closed using a S-Plate v 1.4 force platform Medicapteurs - France, recording the stabilometric variables in relation to wave width in $\mathrm{mm}$, mean deviation in $\mathrm{mm}$, and speed in $\mathrm{mm} / \mathrm{s}$ in the anteroposterior $(\mathrm{A} / \mathrm{P})$ and latero-lateral $(\mathrm{L} / \mathrm{L})$ displacements.

Following the assessment, the patient underwent a vestibular rehabilitation program, twice a week for five consecutive weeks. The canalicular repositioning maneuver and the Epley maneuver were initially performed, and after a period of 48 hours, the rehabilitation program was initiated. The treatment program consisted of Cawthorne-Cooksey vestibular exercises, the Brandt-Daroff modified maneuver, and the Norre's vestibular habituation training.

The rehabilitation program was based entirely on the work of distinguished authors who have influential studies published on the research topic, such as Ganança et al., (2004); Herdman, (2002); Enderle, (2004); Verdiani, (2004) and Ribeiro and Pereira, (2005).

In the first session, the exercises were explained in detail to the patient. The Epley maneuver was performed on the same side in which the patient reported symptoms. It was performed only in the first session, as the positioning nystagmus ceased after it.

The exercises were each performed only once, except for the Brandt-Daroff exercise that was repeated five times for each side. After the intervention, an evaluation was conducted with the same procedures as the initial assessment, and by the same evaluator.

\section{Results}

The results regarding the Romberg test with eyes open did not present statistically significant differences after the rehabilitation intervention (Table 1).

Table 1 - Comparison between wave width, mean deviation, and mean speed in anteroposterior (A/A) and latero-lateral (L/L) displacements with eyes open for initial and final assessments.

\begin{tabular}{lcc}
\hline Displacement (A/A) $\mathbf{~ m m} / \mathbf{s}$ & Initial assessment & Final assessment \\
\hline Wave width & 14,0 & 10,0 \\
Mean deviation & 4,3 & 2,2 \\
Mean Speed & 1,2 & 1,5 \\
\hline Displacement (L/L) $\mathbf{~ m m / s}$ & Initial assessment & Final assessment \\
\hline Wave width & 5,0 & 11,0 \\
Mean deviation & 1,1 & 2,7 \\
Mean Speed & 1,1 & 1,7 \\
\hline
\end{tabular}

Source: Authors (2020).

As shown Table 1, no statistically significant differences were observed in both displacements after treatment intervention compared to before treatment. Although there was a decrease in wave width and mean deviation, and an increase in mean speed, e.g., $0.3 \mathrm{~mm} / \mathrm{s}$ and $0.6 \mathrm{~mm} / \mathrm{s}$ for the anteroposterior and latero-lateral displacements, respectively, the mean speed did not reach statistical significance.

Postural stability, also assessed with eyes open also did not present statistically significant differences after the rehabilitation intervention (Table 2). 
Table 2 - Stabilometric analysis of postural stability with eyes open for initial and final assessments

\begin{tabular}{lcc}
\hline Postural stability & Initial Assessment & Final Assessment \\
\hline Size $(\mathrm{mm})$ & 55,1 & 75,1 \\
Area $\left(\mathrm{mm}^{2}\right)$ & 46,0 & 39,0 \\
Size/Area $(\mathrm{mm})$ & 1,21 & 1,91 \\
Average speed $(\mathrm{mm} / \mathrm{s})$ & 1,6 & 2,3 \\
\hline
\end{tabular}

Source: Authors (2020).

Table 2 shows that despite the decrease in instability area found in the final assessment, the other measures, size, size/area relation, and average speed increased in the final assessment compared to the initial assessment; therefore, not corroborating the improvement in postural instability with eyes open test.

However, both static balance and postural stability, assessed with eyes closed had statistically significant positive results in the post-treatment program, compared to the pre-treatment program.

The Anteroposterior (A/A) and latero-lateral (P/P) displacements, assessed using the Romberg test with eyes closed, are shown in Table 3.

Table 3 - Comparison between wave width, mean deviation, and mean speed in anteroposterior (A/A) and latero-lateral (L/L) displacements with eyes closed for initial and final assessments.

\begin{tabular}{lcc}
\hline Displacement (A/A) $\mathbf{~ m m} / \mathbf{s}$ & Initial assessment & Final assessment \\
\hline Wave width & 11,0 & $5,0^{*}$ \\
Mean deviation & 2,5 & $1,0^{*}$ \\
Mean Speed & 2.0 & $1,7^{*}$ \\
Displacement $(\mathbf{L} / \mathbf{L}) \mathbf{~ m m} / \mathbf{s}$ & Initial assessment & Final assessment \\
Wave width & 10,0 & $8,0^{*}$ \\
Mean deviation & 3,6 & $1,4^{*}$ \\
Mean Speed & 2,5 & $1,8^{*}$ \\
\hline
\end{tabular}

*p<0.05. Source: Authors (2020).

In the eyes closed test, both displacements had a statistically significant improvement in the final assessment compared to the initial assessment, as observed by the decrease in wave width, mean deviation and mean speed.

Postural stability measures with eyes closed also had statistically significant differences between pre and post rehabilitation intervention (Table 4).

Table 4 - Stabilometric analysis of postural stability with eyes closed for initial and final assessments.

\begin{tabular}{lcc}
\hline Postural stability & Initial Assessment & Final Assessment \\
\hline Size $(\mathrm{mm})$ & 103,5 & $82,8^{*}$ \\
Area $\left(\mathrm{mm}^{2}\right)$ & 66,0 & $21,0^{*}$ \\
Size/Area $(\mathrm{mm})$ & 4,91 & $1,31^{*}$ \\
Average speed $(\mathrm{mm} / \mathrm{s})$ & 3,2 & $2,5^{*}$ \\
\hline
\end{tabular}

${ }^{*} \mathrm{p}<0.05$. Source: Authors (2020).

All the parameters analysed in Table 4 had a statistically significant reduction in the final assessment compared to the initial assessment, improving post-treatment postural stability. 


\section{Discussion}

In this case report study, static balance and postural stability were the variables studied in a male patient with VPPB undergoing vestibular rehabilitation. According to Ganança et al., (2004), one in ten people in the world had or have dizziness from vestibular origin. Basseto et al., (2007) reports that vestibular rehabilitation can promote up to a $30 \%$ improvement in vertigo symptoms in $85 \%$ of the individuals submitted to rehabilitation.

The Epley's repositioning maneuver was the selected one for this treatment study. It was performed only in the first session since the positioning nystagmus disappeared after. According to Maia; Diniz and Carlesse (2001), postural restrictions and caution with head movement are recommended for 48 hours after performing the maneuver. The same recommendations were followed in the present study, before initiating the treatment.

Simoceli; Bittar and Gretes (2005) studied the number of necessary maneuvers for the disappearance of nystagmus in VPPB. They found that it was necessary between one and eight maneuvers and that the affected canal did not influence the number of maneuvers.

In addition to the Epley's maneuver, vestibular exercises were incorporated in this study as part of the rehabilitation program. Klober, Azevedo and Soares (2006) studied the influence of vestibular rehabilitation on patients with benign paroxysmal positioning vertigo, who, in addition to the Epley's maneuver, were also subjected to the Cawthorne \& Cooksey, and the modified Brandt-Daroff exercises. The experimental group obtained greater results regarding the management of symptoms and had decreased nystagmus compared to the control group.

In this study, the stabilometric assessment through static baropodometry on a force platform was used to assess the outcome variables. According to Gimenez, (2019), this method measures the patient's spinal vestibule function, providing data for the assessment of patients with dizziness, and also provides analysis of sensorial information.

Stabilometry has been an effective method to assess body balance, and to measure postural oscillation and balance deficit (Pires, et al., 2019). This method has been used in a few studies (Bancoff 2007). According to Bancoff (2004), the analysis of body balance is a recent technology.

Stabilometric measures for the assessment of balance with eyes open did not show statistically significant differences in the present study. Bunday and Bronstein (2009) state that the vestibular system relies greatly on mechanisms of anticipation when stimulated without the assistance of the visual system.

In contrast, the tests with eyes closed, both for static balance and for stability, showed a significant improvement after the treatment compared to before the treatment. Rubira et al. (2010) found similar results. The authors analyzed the efficiency of stabilometric and static baropodometry on balance assessment in patients with vestibular disease. They found that only the average oscillation speed, anteroposterior and latero-lateral displacements with eyes closed had a statistically significant difference.

It has been reported that individuals with vestibular dysfunction are more dependent on the visual system. When assessed with eyes closed the stabilometric measures are markedly altered (Bastos, et al., 2005).

Pimentel, et al., (2020), correlated the influence of vision on orthostatic control through stabilometry. Results showed statistically significant differences only in the closed eyes condition.

It is scientifically proven that vestibular rehabilitation is a great therapeutic option, leading to great results for patients with vestibular disorders. In recent years, intervention proposals, such as the one conducted in this study, has shown evidence regarding the benefits of this method for improving body balance, thus having a positive influence on well-being and quality of life of individuals with vertigo. 


\section{Final Considerations}

This clinical case report study showed the relevance of a rehabilitation program in a rare type of vertigo, the multicanal one. Results from this study lead to conclude that physiotherapy, through vestibular rehabilitation was efficient at improving static balance and postural stability, being a viable option for the treatment of peripheral vestibulopathy.

Future studies aimed at larger samples, examining different length treatment programs should be done in order to broaden this research topic. Additionally, treatment responses in various age groups (e.g, younger adults vs. older adults) should also be examined in order to better understand the efficacy of vestibular rehabilitation programs.

\section{References}

Bancoff, A. D. P., \& Bekedorf, R. (2007). Bases neurofisiológicas do equilíbrio corporal. Revista Digital, 106 (11).

Basseto, J. M., Zeigelboim, B. S., Jurkiewicz, A. L., Ribas, A., \& Marine, R. D. (2007). Reabilitação vestibular em idosos com Parkinson. Revista CEFAC, 9 (2), 269-281.

Bastos, A. G. D., Lima, M. M. T., \& Oliveira, L. F. (2005). Avaliação de pacientes com queixa de tontura e eletronistagmografia normal por meio da estabilometria. Rev. Bras. Otorrinolaringol, 71 (3).

Bunday, K. L., \& Bronstein, A. M. (2008). Locomotor Adaptation and Aftereffects in Patients With Reduced Somatosensory Input Due to Peripheral Neuropathy, J Neurophysiol, 102 (1), 3119-3128.

Enderle, M. S. (2004). Abordagem fisioterapêutica na reabilitação vestibular (Mografia).

Ganança, F. F., Castro, A. S. O., Branco, F. C., \& Natour, J. (2004). Interferência da tontura na qualidade de vida de pacientes com síndrome vestibular periférica. Rev. Bras. Otorrinolaringol, 70 (1).

Ginezes, F. V. (2019). A baropodometria como método de avaliação da distribuição da pressão plantar e estabilometria em portadores de doença de parkinson. (Dissertação).

Herdman, S. J. (2002). Reabilitação vestibular. (2a ed.), Manole.

Klober, M. C., Azevedo, V. F. O., \& Soares, A. V. (2006). A influência da reabilitação vestibular em pacientes com vertigem posicional paroxística benigna. Fisioterapia em Movimento, 19 (2), 37-47.

Maia, R. A., Diniz, F. L., \& Carlesse, A. (2001). Manobras de reposicionamento no tratamento da vertigem paroxística posicional benigna. Rev. Bras. Otorrinolaringol, 67 (5).

Menezes, A. B., Silva, R. S., \& Jorge, F. S. (2020). Baropodometric and stabilometric evaluation of active and sedentary elderly. Online Perspectives Journal: Biological \& Health, 34 (10).

Oliveira, M. V. G., Flora, G. S., Machado, L. A., Silva, R. M. G. C, \& Brum, S. O. (2020). Vertigem posicional paroxística benigna (VPPB): Revisão integrativa. Brazilian Journal of Development, 9 (6), 66970-66977.

Pereira, AS et al. (2018). Metodologia da pesquisa científica. UFSM.

Pimentel, B. N., Rosa, R. R., \& Santos, V. A. V. (2020). Impacto da cefaléia no equilíbrio postural e na percepção da tontura em mulheres. Research, Society and Developmen, 9 (2), 1-15.

Pires, J., Coelho, T., Ferreira, M., Carvalho, F., Grade, E., Alberto, L., \& Silva, A. M. A. L. (2019). Hipofunção vestibular periférica: Quais os fatores de prognóstico da reabilitação vestibular? Revista Portuguesa de Otorrinolaringologia e Cirurgia de Cabeça e Pescoço, 56 (1), 17-22.

Ribeiro, A. S. B., \& Pereira, J. S. (2005). Melhora do equilíbrio e redução da possibilidade de queda em idosas após os exercícios de Cawthorne e Cooksey. Rev. Bras. Otorrinolaringol, 71 (1), 38-46.

Rubira, A. P. F. A., Martins, M. S. E., Denti, C. B. S., Gerlin, N. G., Tomaz, C., \& Rubira, M. C. (2010). Eficiência da estabilometria e baropodometria estática na avaliação do equilíbrio em pacientes vestibulopatas. Neurobiologia, 73 (2).

Simoceli, L., Bittar, R. S. M., \& Gretesrs, M. E. (2005). Restrições posturais não interferem nos resultados da manobra de reposição canalicular. Rev. Bras. Otorrinolaringol, 71 (1), 55-59.

Verdiani, J. (2004). Atuação fisioterapêutica em pacientes com desordens vestibulares periféricas. (Monografia). 